\title{
ADVANTAGE OF THE WHITE EYE MUTANT OF DROSOPHILA MELANOGASTER OVER THE WILD TYPE IN AN ARTIFICIAL ENVIRONMENT
}

\author{
S. C. HARLAND and ANGELA R. HAYGARTH JACKSON \\ Botany Department, University of Manchester
}

Received 14. iii.57

\section{INTRODUCTION}

Most mutants of Drosophila melanogaster are at a disadvantage compared with the wild type in environmental conditions provided by nature. It is a truism of genetics to state that the wild type gene is so because mutative deviants cannot compete with it. For this reason the mutant types of the laboratory are infrequent in nature. In some Drosophila experiments of Gordon (1935), ebony and wild type flies were simultaneously released in a locality in which neither form was present. The frequency of ebony rapidly decreased in five to six generations from $5^{0}$ to I $\mathrm{p}$ per cent. Gordon believed that the heterozygote as well as the recessive was at a disadvantage compared with the wild type.

If, however, the environment is changed so that it is novel both for the wild type and the mutant, it is conceivable that some specific environment might enable a mutant allele to be at an advantage compared with the wild type. It is even possible to imagine selective rates of multiplication of flies possessing wild type and mutant alleles respectively to be so altered that the latter would either replace the former, or cause a new system of gene frequencies to be set up. This would occur if certain features of the environment favoured the wild type and the mutant at different times.

Different genotypes probably always have different reproductive rates over the whole or part of the environmental spectrem found in nature. It is therefore important to explore the environmental contexts in which genotypes differing mainly in a single allele manifest different types of behaviour affecting their reproductive rates. If different types of environmental reaction are inherited and unusual environments are differentially sought, a new equilibrium will be set up between mutant and wild type.

The general object of the experiments described here was to see whether an environment can be devised in which the white eye mutant of Drosophila melanogaster would be at an advantage compared with the wild type.

\section{PRELIMINARY EXPERIMENTS}

The idea underlying the experimental work was to see if selection effects for migratory or olfactory reaction could be detected under 
conditions in which flies would experience difficulty in finding food.

Various kinds of apparatus were considered, among them the complicated types devised by McIndoo (1926, I933) for testing olfactory discrimination in insects. All these were rejected in favour of a simpler form of apparatus which would serve to expose the differential migratory capacities and olfactory reactions of wild type and mutant.

\section{The apparatus}

The apparatus used consisted of three half-pint milk bottles with rubber bungs connected by $4 \mathrm{~mm}$. bore glass tubing. There were two leads of similar length $(50 \mathrm{~cm}$.) from the central bottle $A$, one connected with $\mathrm{G}$ an empty bottle and the other connected with B, a bottle containing the standard food of conventional type, in which to prevent mould growth, the yeast was a propionic acid resistant strain. All glass tubing was covered with black insulating tape to exclude light.

The three bottles were each enclosed in lightproof cardboard boxes, cotton wool being packed round the tubing where it entered the boxes. The flies were thus in complete darkness throughout the period of the experiment.

\section{Preliminary experiment 1}

The preliminary experiment which led to the extended use of this apparatus may now be described.

A mixture of 224 red-eyed flies from a mixture of several geographical strains (hereinafter known as G.S.) kept in mass culture for several generations together with 6 white-eyed flies of diverse origin, were placed in bottle A. After 24 hours the flies in the three bottles were counted and classified.

The results wore :

Bottle A (the original bottle) 74 red females, 93 red males, I white male.

Bottle B (with food) I 3 red females, I red male, 2 white females, and 3 white males.

Bottle C (empty) 23 red females, and 20 red males.

The striking feature of this experiment was that of 6 white-eyed flies, 5 had migrated to the food bottle, indicating a tendency to a high proportional migration to food of the white mutant compared with the wild type.

It was at this point that the experimental material took the form of a mixture of equal numbers of red-eyed females, red-eyed males, white-eyed females and white-eyed males. These, placed in the 
central bottle, were given equal opportunities of migration in the dark to another empty bottle or to a bottle containing food.

Although little seems to be known about the migratory propensities of flies in light and darkness respectively, it was considered desirable to conduct all further experiments in the dark. The reasons for this decision were :

I. The difficulty of equal illumination for all parts of the apparatus.

2. Variations in natural daylight might differentially affect mutant and wild type.

3. The difficulty of satisfactory lighting at night.

In experiments conducted in daylight, flies reaching the rubber connections joining the glass tubing turned round and went back. It was also observed that flies were deterred from entering the dark regions where the tubes passed through the rubber bungs.

\section{Preliminary experiment 2}

The experiment was set up to reveal the relative ability of males and females of both red- and white-eyed stocks to find a bottle containing food in a dark room at a controlled temperature of $25^{\circ} \mathrm{C}$. A half-pint milk bottle containing the normal propionic acid food medium was placed in the middle of the room. Two hundred flies were released simultaneously in the dark room, as far away as possible from the food bottle. They comprised 50 red females and 50 red males from the G.S. stock, and 50 white females and 50 white males from the Cambridge white stock. The flies had been without food and water for two hours before release.

Every half hour the food bottle was replaced by a fresh one. After 6 hours the flies caught in the I 2 food bottles comprised 22 redeyed females, I4 red-eyed males, but no white-eyed flies.

It seems that under these special conditions in which the flies were able to migrate freely, the reds were superior to the whites in their ability to find food.

\section{THE MAIN EXPERIMENTS}

In all the following experiments the 3-bottle apparatus was used.

\section{Material}

The flies used consisted of the following races of Drosophila melanogaster.

(I) Cambridge mass culture white. This strain was considerably inbred but may have been somewhat heterogeneous.

(2) A mixture of ten geographical strains of wild type red-eyed (G.S.).

(3) Heterozygous red-eyed females-the $F_{1}$ of the cross G.S. red females by white Cambridge males.

(4) Samarkand red-eyed, from an inbred stock kept going by sister-brother mating for 286 generations.

(5) Lima inbred red-eyed, inbred by sister-brother mating for 36 generations.

(6) The $F_{1}$ hybrid Samarkand female by Lima male. 
At the start of each trial with the apparatus previously described, the flies to be tested were placed in bottle A, and counted 2-3 hours before the beginning of the trial to enable them to recover from the effects of etherisation. Trials were started at about 4 p.m. and 24 hours later the classification of the flies for sex and eye colour was effected.

The food medium. This consisted of the following : $108 \mathrm{gm}$. maize meal ; $12 \mathrm{gm}$. agar powder ; 77 c.c. black treacle ; 520 c.c. water. Six c.c. of propionic acid yeast suspension was added to each bottle of the prepared food.

\section{The experimental results}

Experiment $\mathrm{I}$. To observe the migration from A to B (food) and to $\mathrm{C}$ (no food) of red-eyed females $\left(5^{\circ}\right)$, red-eyed males $\left(5^{\circ}\right)$, whiteeyed females (50) and white-eyed males (50).

The results are given in table $\mathrm{I}$.

TABLE I

Composition of flies which migrated to $B$ (food) and $C$ (no food) in trials with each of two apparatuses, Nos. $I$ and 2. G.S. reds and Cambridge whites

\begin{tabular}{|c|c|c|c|c|c|c|}
\hline $\begin{array}{c}\text { No. of the } \\
\text { apparatus }\end{array}$ & $\begin{array}{c}\text { Red } \\
\text { females }\end{array}$ & $\begin{array}{c}\text { Red } \\
\text { males }\end{array}$ & $\begin{array}{c}\text { White } \\
\text { females }\end{array}$ & $\begin{array}{c}\text { White } \\
\text { males }\end{array}$ & Total & $\begin{array}{c}\text { No. of } \\
\text { trial }\end{array}$ \\
\hline $2 \mathrm{~B}$ & 224 & 281 & 543 & 570 & 1618 & 33 \\
$2 \mathrm{C}$ & 70 & 73 & 70 & 97 & 310 & \\
\hline 1 13 & $4 \mathrm{I}$ & 84 & 99 & 116 & 340 & 20 \\
\hline
\end{tabular}

The results of the 33 trials with apparatus 2, clearly show that whites are about twice as efficient as reds in their ability to migrate to food, and that the sexes are somewhat similar in their response. The males migrate slightly more than the females though the difference is not statistically significant.

The results from bottle $\mathrm{C}$ (no food) indicate no clear differences between reds and whites, or between males and females in each eyecolour class. Comparing migration to food and no food, 1618 flics go to the food bottle and only 3 ro to the no-food bottle. It secms evident that an olfactory response is involved.

The results with apparatus I again indicate that whites (2I5) go to food more often than reds ( 125 ). The ratio of $\mathrm{I} \cdot 72: \mathrm{I} \cdot 00$ in favour of whites may be compared with the ratio of $2 \cdot 20: I \cdot 00$ obtained with apparatus 2.

To be noted is the fact that the type which migrated most was the white male. Noteworthy also was the greatly fluctuating behaviour of the flies in the different trials. The results of single trials are capricious, and it is only when several trials are pooled that the advantage of white is clearly marked. Variation between trials cannot be accounted for by any environmental factor that can be postulated. 
To illustrate the range of variation between the results of trials, a few may be given in detail (for bottle B food) :

\begin{tabular}{|c|c|c|c|c|c|c|c|c|c|}
\hline \multirow{2}{*}{ Classes } & \multicolumn{9}{|c|}{ Trial number } \\
\hline & 10 & 14 & I9 & 20 & 33 & 23 & 24 & $2 \mathrm{I}$ & 29 \\
\hline Red female & 0 & o & 0 & 0 & 0 & 27 & 24 & 17 & I7 \\
\hline Red male & 7 & $\mathrm{o}$ & 4 & o & 9 & 14 & 22 & 13 & 21 \\
\hline White female & 37 & 37 & 0 & 5 & 12 & $3^{8}$ & 30 & 23 & 28 \\
\hline White male & 30 & $4^{\circ}$ & 5 & 7 & 10 & $3^{\circ}$ & 34 & 10 & 25 \\
\hline
\end{tabular}

Trial 14 is of special interest, in that no reds went to food at all, whereas 77 whites did so.

Experiment 2. In this experiment heterozygous red-eyed flies from the cross G.S. reds by Cambridge whites replaced the homozygous reds used in Experiment I.

The results are given in table 2.

TABLE 2

Composition of fies which migrated to $B$ (food) and $C$ (no food) in trials with each of the two apparatuses Nos. $I$ and 2, heterozjgous G.S. reds and Cambridge whites

\begin{tabular}{|c|c|c|c|c|c|c|}
\hline $\begin{array}{l}\text { No. of the } \\
\text { apparatus }\end{array}$ & $\begin{array}{c}\text { Red } \\
\text { females }\end{array}$ & $\begin{array}{l}\text { Red } \\
\text { males }\end{array}$ & $\begin{array}{l}\text { White } \\
\text { females }\end{array}$ & $\begin{array}{l}\text { White } \\
\text { males }\end{array}$ & Total & $\begin{array}{l}\text { No. of } \\
\text { trials }\end{array}$ \\
\hline $\begin{array}{l}2 \mathrm{~B} \\
2 \mathrm{C}\end{array}$ & $\begin{array}{l}12 \\
11\end{array}$ & $\begin{array}{r}71 \\
13^{8}\end{array}$ & $\begin{array}{l}58 \\
21\end{array}$ & $\begin{array}{l}92 \\
36\end{array}$ & $\begin{array}{l}233 \\
206\end{array}$ & I5 \\
\hline $\begin{array}{l}\text { B B } \\
1 \mathrm{C}\end{array}$ & $\begin{array}{r}23 \\
7\end{array}$ & $\begin{array}{r}133 \\
46\end{array}$ & $\begin{array}{l}75 \\
11\end{array}$ & $\begin{array}{r}9^{8} \\
9\end{array}$ & $\begin{array}{r}329 \\
73\end{array}$ & 15 \\
\hline
\end{tabular}

The main points of importance in table 2 are as follows :

\section{Apparatus 2.}

I. The number of flies migrating to food (B) is only slightly greater than the number which migrated to no food $(C)$. (233:206).

2. The flies which migrated to food consisted of 150 whites and 83 reds, and the advantage of white over red is again obvious.

3. The migrating capacity of heterozygous reds where four types are present is very low. Under these particular experimental conditions, the substitution of heterozygous red females for homozygous was not advantageous but rather the reverse.

4. The proportion of males to females migrating to both food and no food differed significantly from equality. For food the ratio was I6 3 males to 70 females, and for no food I 74 males to 32 females.

5. In flies which migrated to no food the advantage was with red and not with white. This is chiefly due to the large excess of red 
males which considerably outnumbered the total of the other three classes ( 139 red males to 63 -the rest).

Considering the results of apparatus I, the main features are as follows :

I. The number of flies migrating to food is much greater than the number which went to no food $(329: 73)$. The olfactory reaction came into play in this experiment, although with apparatus 2 it was only slight.

TABLE $_{3}$

Composition of flies which migrated to $B$ (food) and $C$ (no food) in trials with. five apparatuses. Material-Lima inbred reds and Cambridge whites

\begin{tabular}{|c|c|c|c|c|c|c|}
\hline $\begin{array}{l}\text { No. of the } \\
\text { apparatus }\end{array}$ & $\begin{array}{c}\text { Red } \\
\text { females }\end{array}$ & $\begin{array}{c}\text { Red } \\
\text { males }\end{array}$ & $\begin{array}{l}\text { White } \\
\text { females }\end{array}$ & $\begin{array}{l}\text { White } \\
\text { males }\end{array}$ & Total & $\begin{array}{l}\text { No. of } \\
\text { trials }\end{array}$ \\
\hline $\begin{array}{ll}2 & B \\
2 & C\end{array}$ & $\begin{array}{r}87 \\
4\end{array}$ & $\begin{array}{r}101 \\
6\end{array}$ & $\begin{array}{r}195 \\
8\end{array}$ & $\begin{array}{r}214 \\
8\end{array}$ & $\begin{array}{r}597 \\
26\end{array}$ & 15 \\
\hline $\begin{array}{l}1 \mathrm{~B} \\
\mathrm{I} \mathrm{C}\end{array}$ & $\begin{array}{l}3 \\
0\end{array}$ & $\begin{array}{l}9 \\
3\end{array}$ & $\begin{array}{l}34 \\
12\end{array}$ & $\begin{array}{l}94 \\
61\end{array}$ & $\begin{array}{r}140 \\
76\end{array}$ & 15 \\
\hline $\begin{array}{l}3 \mathrm{~B} \\
3 \mathrm{C}\end{array}$ & $\begin{array}{l}1 \\
0\end{array}$ & $\begin{array}{l}2 \\
1\end{array}$ & $\begin{array}{r}56 \\
8\end{array}$ & $\begin{array}{r}56 \\
7\end{array}$ & $\begin{array}{r}115 \\
16\end{array}$ & 5 \\
\hline${ }_{4}^{4} \stackrel{\mathrm{B}}{\mathrm{C}}$ & $\begin{array}{l}9 \\
2\end{array}$ & $\begin{array}{r}11 \\
2\end{array}$ & $\begin{array}{r}57 \\
7\end{array}$ & $\begin{array}{l}60 \\
14\end{array}$ & $\begin{array}{r}137 \\
25\end{array}$ & 5 \\
\hline $\begin{array}{l}5 \mathrm{~B} \\
5 \mathrm{C}\end{array}$ & $\begin{array}{l}39 \\
18\end{array}$ & $\begin{array}{l}37 \\
20\end{array}$ & $\begin{array}{l}76 \\
30\end{array}$ & $\begin{array}{l}63 \\
4^{2}\end{array}$ & $\begin{array}{l}215 \\
110\end{array}$ & 5 \\
\hline
\end{tabular}

2. The flies which migrated to food consisted of 173 whites to 156 reds. The advantage of white over red was small. The red-eyed males once more constituted the largest class.

3. Only 73 flies migrated to no food, the red-eyed males again being the largest class. Here there was no advantage of white over red, but rather the reverse ( 53.3 red to 20 white).

Experiment 3. In this experiment, the inbred line of Lima (50/I I), replaced the G.S. reds of Experiment I. In addition to I 5 trials with apparatuses $I$ and 2, 5 trials were made with each of three more apparatuses.

The results of this experiment are given in table 3 .

In these experiments the advantage of white over red in the capacity to go to the food bottle was very great, the numbers for the 5 apparatuses being 3 I9 red to 905 white.

It should be remembered, however, that inbreeding of the Lima strain must certainly have caused some depression in vigour and thus 
the relative advantage of white is probably not due to the simple monogenic difference between the stocks but to inbreeding depression.

\section{TABLE 4}

Composition of flies which migrated to $B$ (food) and $C$ (no food) in trials with three apparatuses. Material-Samarkand inbred reds and Cambridge whites

\begin{tabular}{|c|c|c|c|c|c|c|}
\hline $\begin{array}{l}\text { No. of the } \\
\text { apparatus }\end{array}$ & $\begin{array}{c}\text { Red } \\
\text { females }\end{array}$ & $\begin{array}{c}\text { Red } \\
\text { males }\end{array}$ & $\begin{array}{l}\text { White } \\
\text { females }\end{array}$ & $\begin{array}{l}\text { White } \\
\text { males }\end{array}$ & Total & $\begin{array}{l}\text { No. of } \\
\text { trials }\end{array}$ \\
\hline $\begin{array}{l}3 \mathrm{~B} \\
3 \mathrm{C}\end{array}$ & $\begin{array}{l}6 \\
0\end{array}$ & $\begin{array}{r}26 \\
0\end{array}$ & $\begin{array}{r}203 \\
4\end{array}$ & $\begin{array}{r}232 \\
5\end{array}$ & $\begin{array}{r}467 \\
9\end{array}$ & I 3 \\
\hline $4 \underset{4}{\mathrm{C}}$ & I & $\begin{array}{l}6 \\
0\end{array}$ & $\begin{array}{r}127 \\
3\end{array}$ & $\begin{array}{r}146 \\
4\end{array}$ & $\begin{array}{r}280 \\
7\end{array}$ & I 3 \\
\hline $\begin{array}{l}5 \\
5\end{array}$ & $\begin{array}{r}14 \\
0\end{array}$ & $\begin{array}{r}26 \\
2\end{array}$ & $\begin{array}{r}243 \\
10\end{array}$ & $\begin{array}{r}227 \\
17\end{array}$ & $\begin{array}{r}510 \\
29\end{array}$ & I3 \\
\hline
\end{tabular}

Experiment 4. This experiment was similar to Experiment 3, except that the mixed G.S. reds were replaced by Samarkand inbreds. The Samarkand line had been inbred for 286 generations. The results are given in table 4 .

TABLE 5

Composition of the flies which migrated to $B$ (food) and $C$ (no food) in trials with three apparatuses. Material-hybrid Samarkand $\times$ Lima, and Cambridge whites

\begin{tabular}{|c|c|c|c|c|c|c|}
\hline $\begin{array}{l}\text { No. of the } \\
\text { apparatus }\end{array}$ & $\begin{array}{c}\text { Red } \\
\text { females }\end{array}$ & $\begin{array}{l}\text { Red } \\
\text { males }\end{array}$ & $\begin{array}{l}\text { White } \\
\text { females }\end{array}$ & $\begin{array}{l}\text { White } \\
\text { males }\end{array}$ & Total & $\begin{array}{c}\text { No. of } \\
\text { trials }\end{array}$ \\
\hline $\begin{array}{l}3 \mathrm{~B} \\
3 \mathrm{C}\end{array}$ & $\begin{array}{r}\text { II } \\
0\end{array}$ & $\begin{array}{r}4 \mathrm{I} \\
0\end{array}$ & $\begin{array}{r}61 \\
5\end{array}$ & $\begin{array}{r}53 \\
9\end{array}$ & $\begin{array}{r}166 \\
14\end{array}$ & 5 \\
\hline $\begin{array}{l}4 \mathrm{~B} \\
4 \mathrm{C}\end{array}$ & $\begin{array}{l}\text { I } \\
\text { o }\end{array}$ & $\begin{array}{l}4 \\
3\end{array}$ & $\begin{array}{r}14 \\
4\end{array}$ & $\begin{array}{r}16 \\
7\end{array}$ & $\begin{array}{l}35 \\
14\end{array}$ & 5 \\
\hline $\begin{array}{l}5 \mathrm{~B} \\
5 \mathrm{C}\end{array}$ & $\begin{array}{r}23 \\
0\end{array}$ & $\begin{array}{r}6 \mathrm{I} \\
5\end{array}$ & $\begin{array}{l}77 \\
13\end{array}$ & $\begin{array}{l}77 \\
23\end{array}$ & $\begin{array}{r}23^{8} \\
41\end{array}$ & 5 \\
\hline
\end{tabular}

These results are similar to those of Experiment 3. The activity of the Samarkand strain is very low, being even less than that of the Lima inbreds. The comparison here is rather one of lack of vigour through inbreeding, and the great difference in activity betwcen red and white has probably no bearing on the main object of the experiments.

Experiment 5. In this experiment the red-eyed flies consisted of the $F_{1}$ of the cross Samarkand $\times$ Lima the two highly inbred strains. The results are given in table 5 . 
These results indicate that the first generation hybrid between Samarkand and Lima is more active than either of the two long inbred parent strains. The increased activity may be ascribed to heterosis. The presumed heterotic condition raises the activity of

TABLE 6

Migration to food of reds of different origin compared with standard Cambridge white

\begin{tabular}{|c|c|c|c|}
\hline \multirow{2}{*}{ Source of reds } & \multicolumn{2}{|c|}{ Number going to food } & Ratio \\
\hline & White & Red & White to red \\
\hline $\begin{array}{l}\text { Geographical races } \\
\text { Lima inbred } \\
\text { Samarkand inbred } \\
F_{1} \text { Samarkand } \times \text { Lima }\end{array}$ & $\begin{array}{r}1127 \\
905 \\
\text { I } 78 \\
298\end{array}$ & $\begin{array}{r}630 \\
299 \\
79 \\
141\end{array}$ & $\begin{array}{r}2 \cdot \mathrm{I}: \mathrm{I} \cdot \mathrm{O} \\
3 \cdot \mathrm{O}: \mathrm{I} \cdot 0 \\
\mathrm{I} 4 \cdot 9: \mathrm{I} \cdot 0 \\
2 \cdot \mathrm{I}: \mathrm{I} \cdot 0\end{array}$ \\
\hline
\end{tabular}

the $F_{1}$ to a level comparable with that of the G.S. stock. In support of the main conclusion from Experiment $I$ that under these experimental conditions white has an advantage over red, it is important to note that even with maximum heterotic vigour of the reds, there is still a 2 to I advantage in favour of white.

\section{TABLE 7}

Classification of red females into homozygous and heterozygous migrating to food and no food respectively

\begin{tabular}{|c|c|c|c|}
\hline $\begin{array}{c}\text { No. of the } \\
\text { apparatus }\end{array}$ & Heterozygous & Homozygous & No. of trials \\
\hline 2 B & 224 & I3I & 20 \\
2 C & 66 & $5 \mathrm{I}$ & \\
\hline I B & I29 & 68 & 20 \\
I C & 5 & I6 & \\
\hline
\end{tabular}

A summarised comparison of the behaviour of various reds with Cambridge white is given above in table 6 .

Experiment 6. Although in Experiment 2 the substitution of redeyed heterozygous females for homozygous ones did not point to an advantage in favour of the heterozygous form, but rather the contrary, it was decided to compare directly the behaviour of heterozygous and homozygous reds, using females only.

Homozygous reds came from the G.S. stock. Heterozygous reds came from a mating of 5 G.S. red females and 5 Cambridge white males. The number of flies which took part in each trial was $5^{\circ}$, consisting of 25 homozygous and 25 heterozygous flies. 
Migrating flies were classified into heterozygotes or homozygotes by means of a test mating with Cambridge white males, three of which were confined with each female to ensure offspring. The results are given in table 7 .

From this table it is clear that :

I. Heterozygotes migrating to food considerably outnumber homozygotes, the ratio being $I \cdot 7: I \cdot O$ in apparatus 2 and $I \cdot 9: I \cdot O$ in apparatus $\mathrm{I}$.

2. In flies migrating to no food there was a slight advantage $(66: 5 \mathrm{I})$ of the heterozygote in apparatus 2 and a much greater advantage in apparatus $I$ ( 5 I : I6).

\section{DISCUSSION}

It is evident from the results of the experiments that migratory movement per se is distinct from movement due to olfactory response. Olfactory response is the reaction of the flies to the stimulus of food. Migratory behaviour is no doubt due to interaction of genotypes of different degrees of vitality, wiik the general environment, ard with other factors conditioning chance restlessness of a random nature. Such environmental factors as temperature and humidity seem to play little part.

The sum total of causes promoting mobility causes great and uncontrollable variation between trials.

The results in every experiment showed that more flies migrated to food than to no food, so that some sort of olfactory response is involved. Olfactory reaction is thus superimposed on capricious nobility. Flies going to food will do so for more than one reason. All will have migratory capacity. Some will reach food by pure chance. Others will have purposively responded to the stimulus of food. Chance meandering probably accounts for the flies going to the empty bottle.

In most experiments, males were generally more mobile than females, though the advantage of males over females was not always statistically significant.

Migratory behaviour of red-eyed males and females tends to be similar, as is also the behaviour of white-eyed members of both sexes. The behaviour of the reds is largely independent of the whites.

The migratory activity of the standard Cambridge white stock is about twice as great as that of the G.S. red-eyed stock. Inbreeding by prolonged sister-brother mating reduces greatly the migratory activity of red-eyed flies of the two inbred stocks, Lima and Samarkand. The inbred Lima line has only one-third and the inbred Samarkand only about one-fifteenth of the migratory activity of the Cambridge whites. The difference in migratory capacity between the two inbred stocks may be due either to genetical factors for vigour, or to a more prolonged period of inbreeding in the Samarkand stock. 
The cross between Samarkand and Lima stocks is more active than either parent and is in fact as active as the extremely heterozygous mixed geographical race. It seems that heterosis augments both migratory and olfactory reaction but even with the maximum heterotic effect obtainable, the whites have a 2 to I advantage over the reds.

A possible criticism is that the genetical background in which the white mutant is manifested, might have imparted a greater degree of vigour to this race, and that the genetical background and not the white gene was the predominant factor in causing superior mobility and olfactory response. This is unlikely, because various genotypes of red-eyed flies were used, and none, even the most heterotic, had a migratory capacity equal to the Cambridge whites.

In a direct comparison between reds of the G.S. homozygous and heterozygous red-eyed females (G.S. $\times$ Cambridge white), with no males present, the heterozygotes had a greater migratory capacity and a greater olfactory response. But when heterozygotes were substituted for homozygotes in the presence of male and female whites they seemed to be at a disadvantage compared with homozygous females under similar conditions.

\section{SUMMARY}

Under the special cnvironmental conditions described here, and novel to both the red-eyed wild type and the mutant white Cambridge stock of Drosophila melanogaster, the white is at an advantage, and the heterozygous red-eyed females may have an advantage over homozygotes.

\section{REFERENCES}

GORDON, C. 1935. An experiment in a released population of Drosophila melanogaster. Amer. Nat., 69, 38 r.

MCindoo, N. E. 1926. An insect olfactometer. 7. Econ. Ent., 19, 545.

MCINDOO, N. E. 1933. Olfactory responses of blowflics without antennæ, in a wooden olfactometer. J. Agr. Res.; $\neq^{f 5,607 .}$ 